See discussions, stats, and author profiles for this publication at: https://www.researchgate.net/publication/242329883

\title{
Neactaeonina argentina, New Species, and Family Placement of the Genus Neactaeonina Thiele, 1912 (Mollusca: Gastropoda)
}

Article in Malacologia - March 2011

DOI: $10.4002 / 040.053 .0204$

CITATIONS

4

3 authors:

Diego G Zelaya

University of Buenos Aires

61 PUBLICATIONS 366 CITATIONS

SEE PROFILE

A.

Cristián Ituarte

Museo Argentino de Ciencias Naturales "Bernardino Rivadavia"

85 PUBLICATIONS 813 CITATIONS

SEE PROFILE

Some of the authors of this publication are also working on these related projects:

Estimado Enrique, te agradeceré un PDF de tu artículo. View project

Ecological and systematic studies in the Argentinean shelf-break front: the Patagonian scallop fishing grounds View project
READS

96

Laura Schejter

National Institute for Fisheries Research and Development, CONICET, IIMYC 65 PUBLICATIONS 539 CITATIONS

SEE PROFILE 


\title{
NEACTAEONINA ARGENTINA, NEW SPECIES, AND FAMILY PLACEMENT OF THE GENUS NEACTAEONINA THIELE, 1912 (MOLLUSCA: GASTROPODA)
}

\author{
Diego G. Zelaya ${ }^{1}, 2^{\star}$, Laura Schejter ${ }^{3}$ \& Cristián Ituarte 4
}

\begin{abstract}
Neactaeonina argentina, a new species from the outer Argentine shelf off Buenos Aires province, is described. The species is characterized by the elongate, low-spired shell, with shouldered, nearly straight whorls, deep suture, and sculpture composed of numerous, broad, flat spiral cords. The radula is similar to that previously described for the type species, Neactaeonina cingulata Thiele, 1912, except in having a greater number of teeth. The present study provides the first information on the anatomy and histology of the genital system, and details of the radula anatomy of Neactaeonina, both unknown to date. The study of anatomical characters demonstrates that Neactaeonina has clear similarities with other Acteonidae, with a combination of features present in Acteon (such as the presence of a strongly calcified shell, with well-developed operculum; mantle cavity opening anteriorly; nervous system with only the cerebropleural ganglia fused; a single allosperm sac associated with the female system; radula without cardinal tooth; and oral cuticle with rod-like processes); and some characters present in acteonid genera other than Acteon (e.g., the number and morphology of teeth, and processes of the oral cuticle). However, Neactaeonina shows some characters thus far not reported for any other genus currently placed into the Acteonidae: salivary glands with laminar structure, male genital system with an open portion, a single allosperm sac opening distally, and a flat and triangular copulatory organ.

Keywords: Gastropoda, Acteonidae, Neactaeonina, Southern Ocean.
\end{abstract}

\section{INTRODUCTION}

Neactaeonina was proposed by Thiele (1912) to include three species from sub-Antarctic and Antarctic waters: Actaeonina cingulata Strebel, 1908 (type species) from South Georgia; Actaeon (sic) edentulus Watson, 1889 from Kerguelen Islands, and Neactaeonina fragilis Thiele, 1912, from the Davis Sea of eastern Antarctica. Subsequently, Dell (1956) described a fourth species, Neactaeonina inexpectata, from Chatham Rise, off New Zealand.

The descriptions of sub-Antarctic and Antarctic Neactaeonina species were based on subtle morphological shell characters observed in few specimens, if not on a single specimen. Differential characters were never clearly described, resulting in a confusing taxonomy and mistaken identifications. In this regard, for instance, Powell (1951) reported specimens from South Georgia and South Shetlands
Islands as Neactaeonina edentula, but latter (Powell, 1960) considered that these records correspond either "to [N.] cingulata or to a new species".

The familial assignment of the genus has never been properly discussed. Odhner (1926), based on the radula morphology described by Thiele (1912), placed Neactaeonina in the Acteonidae. New information on anatomy and radular morphology of a new species of Neactaeonina from the Argentine continental shelf described here, allowed a revision of the systematic position of the genus.

\section{MATERIALS AND METHODS}

The specimens described here were collected by the BIP "Capitán Cánepa" (Instituto Nacional de Investigación y Desarrollo Pesquero, INIDEP) during routine cruises for stock assess-

1División Zoología Invertebrados, Museo de La Plata, Paseo del Bosque s/n, 1900, La Plata, Argentina 2Departamento Biodiversidad y Biología Experimental, Facultad de Ciencias Exactas y Naturales, UBA, Argentina 3Instituto Nacional de Investigación y Desarrollo Pesquero (INIDEP). Paseo Victoria Ocampo 1, BH7602 Mar del Plata, Argentina 4Museo Argentino de Ciencias Naturales, Ángel Gallardo 470, C1405DJR Ciudad de Buenos Aires, Argentina

*Corresponding author: dzelaya@fcnym.unlp.edu.ar 


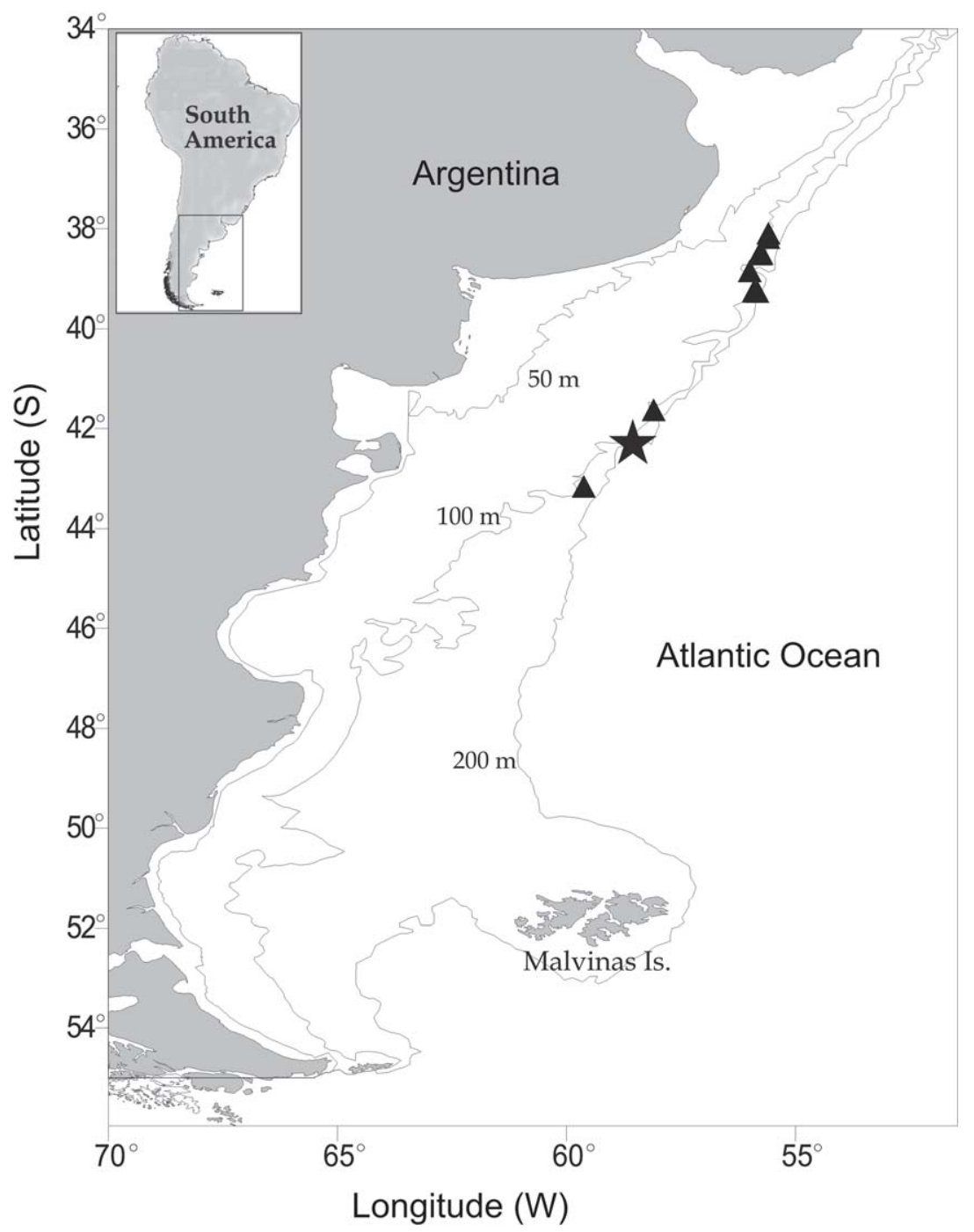

FIG. 1. Location map. Type locality ( $\star$ ); other material examined $(\boldsymbol{\Delta})$

ment of the Patagonian scallop Zygochlamys patagonica (King, 1832). Benthic samples were collected using a non-selective dredge $(2.5 \mathrm{~m}$ mouth aperture). Gastropods were sorted, fixed in a $5 \%$ formalin solution, and preserved in $75 \%$ alcohol. Voucher specimens were deposited in the malacological collection at Museo de La Plata (MLP), La Plata and Museo Argentino de Ciencias Naturales "Bernardino Rivadavia" (MACN), Buenos Aires. For comparative purposes, the types or photographs of the type specimens of other species of Neactaeonina were examined: Museum of New Zealand Te Papa Tongarewa (NMNZ), Wellington, New Zealand [N. inexpectata]; The Natural History Museum (BMNH), London, United Kingdom [N. edentula]; Swedish Museum of Natural History (SMNH), Stockholm, Sweden [N. cingulata]; and Zoologisches Museum (ZMB), Berlin, Germany [N. fragilis].

Gross anatomy was studied by dissection under a stereoscopic microscope; the radula was dissected, cleaned by rising in a commer- 


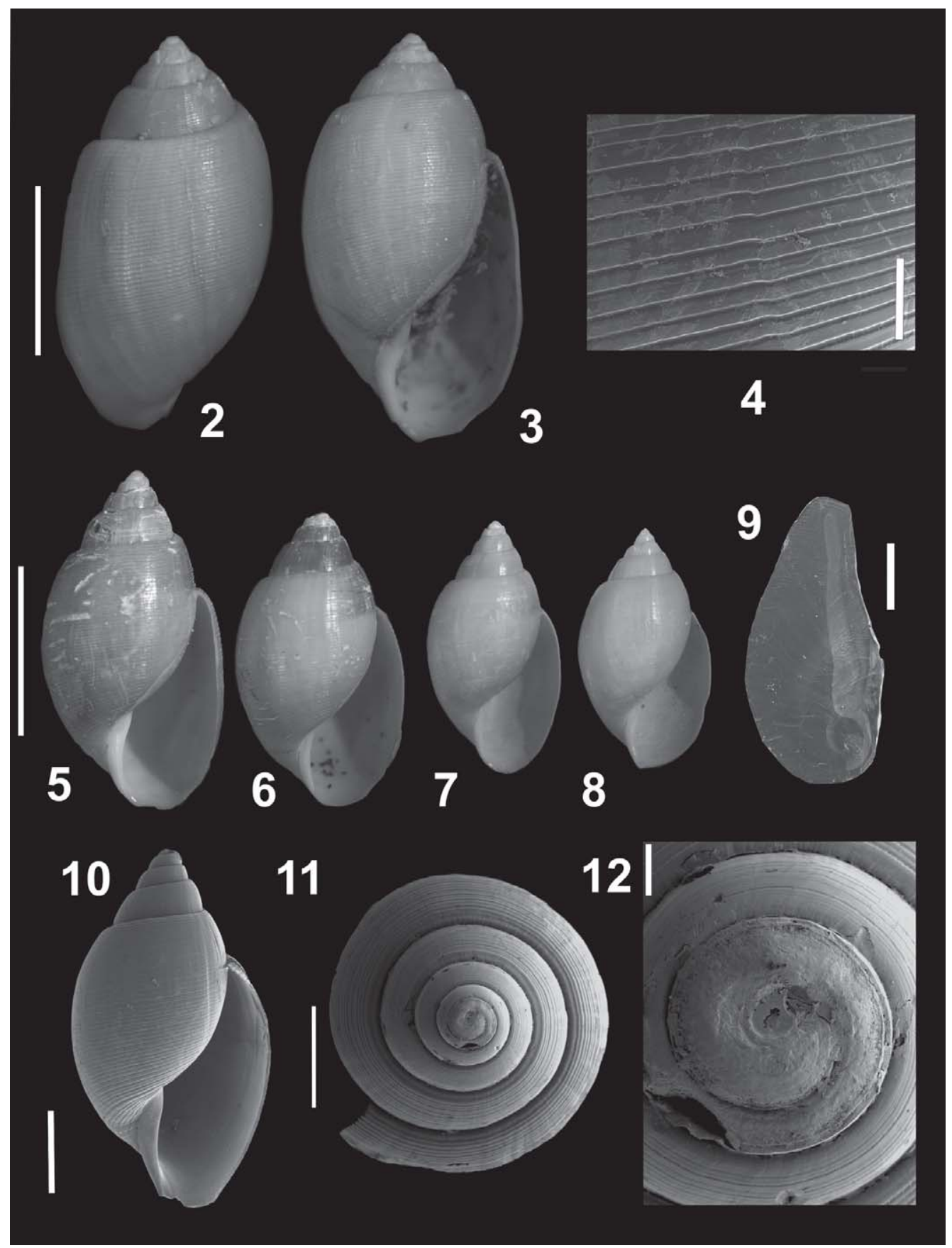

FIGS. 2-12. Neactaeonina argentina, new species. FIGS. 2, 3: Holotype (MLP 13264). FIG. 2: Dorsal view; FIG. 3: Apertural view. FIGS. 4-8: Paratypes. FIG. 4: Detail of shell sculpture; FIGS. 5-8: Ontogenetic series; FIG. 9: Operculum. FIGS. 10-12: Specimen from $38^{\circ} 09.88^{\prime} \mathrm{S}$, 55 $35.42^{\prime} \mathrm{W}$ (MACN-In 38141). FIG. 10: Apertural view (SEM); FIG. 11: Apical view; FIG. 12: Detail of protoconch. Scale bars FIGS. 2, 3, 5-8 = $10 \mathrm{~mm}$; FIGS. 4, $12=200 \mu \mathrm{m}$; FIG. $9=1 \mathrm{~mm}$; FIGS. $10,11=2 \mathrm{~mm}$. 

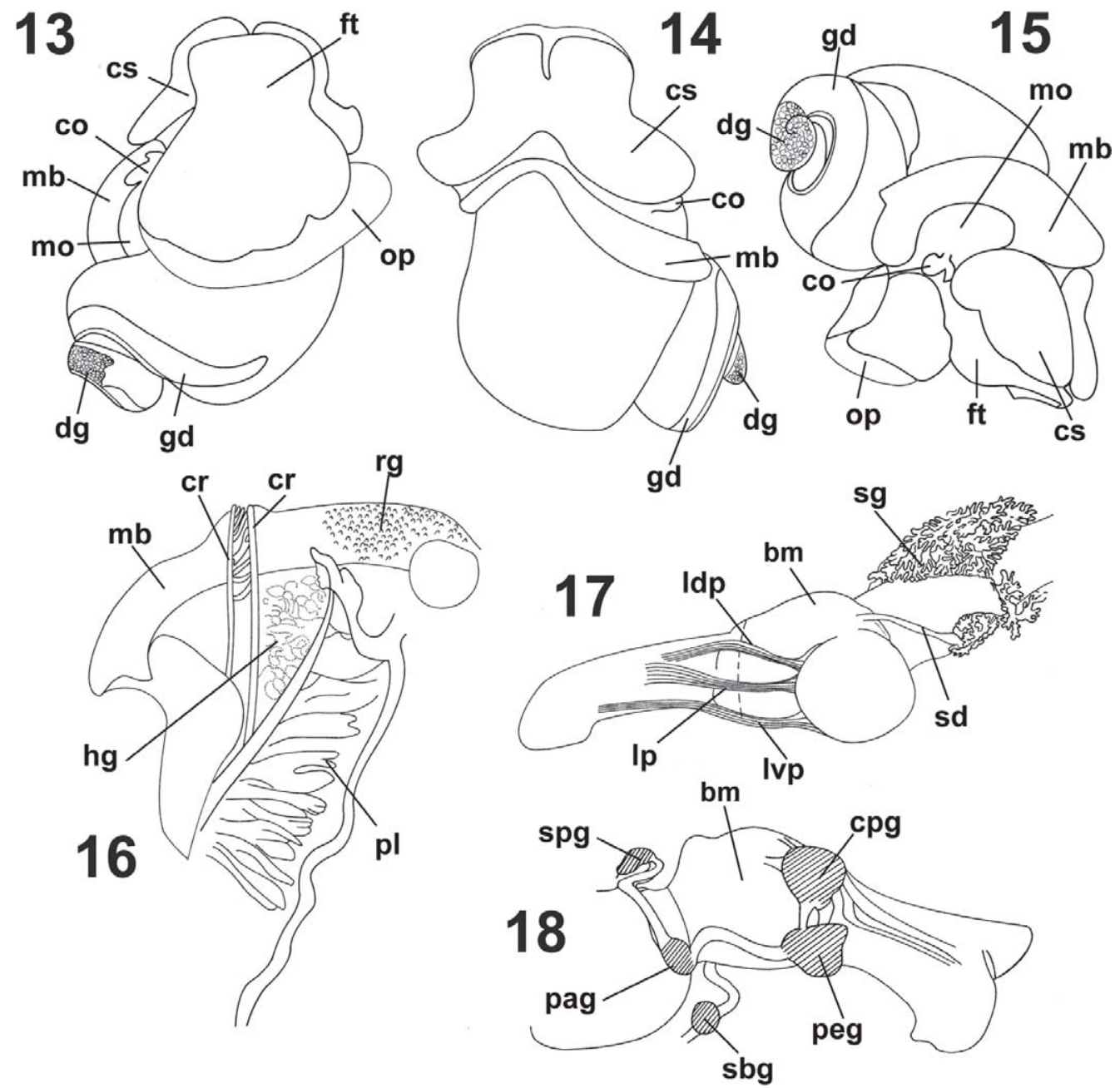

FIGS. 13-18. Neactaeonina argentina, new species: gross anatomy. FIG. 13: Ventral view; FIG. 14: Dorsal view; FIG. 15: Lateral view; FIG. 16: Detail of the roof of the pallial cavity; FIG. 17: Anterior part of digestive system; FIG. 18: Nervous system. bm: buccal mass; co: copulatory organ; cpg: cerebropleural ganglion; cr: ciliated ridge; cs: cephalic shield; dg: digestive gland; ft: foot; gd: gonad; hg: hypobranchial gland; Idp: laterodorsal protractor muscle; Ip: lateral protractor muscle; Ivp: lateroventral protractor muscle; mb: mantle border; mo: mantle opening; op: operculum; pag: pallial ganglion; peg: pedal ganglion; pl: plicatidium; rg: repugnatorial glands (?); sbg: subesophageal ganglion; sd: salivary duct; sg: salivary gland; spg: suprapharyngeal ganglion.

cial sodium hypochlorite solution, washed in distilled water, and prepared dried for Scanning Electron Microscopy (SEM). Histological serial sections of three specimens were obtained after embedding tissues in Paraplast ${ }^{\circledR}(7 \mu \mathrm{m}$ thick) and Historesin ${ }^{\circledR}(3.5 \mu \mathrm{m}$ thick), and stained with eosin-hematoxylin.

\section{SYSTEMATICS}

\section{Neactaeonina argentina, new species}

Figs. $1-50$

Type Locality: $42^{\circ} 14.12^{\prime} \mathrm{S}, 58^{\circ} 32.97^{\prime} \mathrm{W}$, off Buenos Aires province, $95 \mathrm{~m}$ depth. 
Type Material: Holotype (23.5 mm length) (MLP 13264 ) and 4 paratypes from $38^{\circ} 33.82^{\prime}-$ $38^{\circ} 34.96$ 'S, $55^{\circ} 44.63^{\prime}-55^{\circ} 46.71^{\prime} \mathrm{W}, 84-91$ m (2 paratypes, MLP 13265; 2 paratypes MACN-In 38140).

Other Material Examined: Off Buenos Aires province at: 1 specimen, $38^{\circ} 09.88^{\prime} \mathrm{S}, 5^{\circ} 35.42^{\prime} \mathrm{W}, 94$ m (MACN-In 38141); 5 specimens, $38^{\circ} 55.30^{\prime} S$, 5559.86'W, 84 m (MLP 13266); 1 specimen, 39¹9.86'S, 5554.62'W, 105 m (MLP 13267); 1 specimen, $43^{\circ} 14.18^{\prime} \mathrm{S}, 59^{\circ} 37.27^{\prime} \mathrm{W}, 100 \mathrm{~m}$ (MLP 13268); 1 shell, $41^{\circ} 41.95^{\prime} \mathrm{S}, 5^{\circ} 05.70^{\prime} \mathrm{W}$, 96 m (MLP 13269); 1 specimen, 38¹5.13'S, $55^{\circ} 35.55^{\prime} \mathrm{W}, 97 \mathrm{~m}$ (MACN-In 38142).

\section{Etymology}

The species name refers to Argentina, the country from whose continental shelf the species was collected.

\section{Diagnosis}

Shell solid, spire low, somewhat acute, weakly shouldered and nearly straight-sided whorls, with deep suture. Sculpture of numerous, broad, flat spiral cords. Columellar callus wide. Radular formula: 27-0-27.

\section{Description}

Shell of medium size (maximum observed length $=23.5 \mathrm{~mm}$ ), strongly calcified, globose, elongated, with apex exposed (Figs. 2, 3, 5-8). Protoconch of 1.5 whorls, about $960 \mu$ m diameter (Fig. 12). Teleoconch of up to $4 \frac{3}{4} 4$ whorls. Spire acute, high, with almost straight and shouldered whorls; suture deep (Figs. 2, 3, 5-8, 10-12). Last whorl enlarged, ovate, inflated, particularly in small specimens (Figs. 2, 3, 5-8, 10, 11). Aperture elongate, about $65-70 \%$ of shell high, wider anteriorly. Outer lip thin, evenly curved. Columella slightly arcuate, nearly straight at the base, smooth. Columellar callus narrow, white, stronger anteriorly. Shell sculptured with broad, flat, regularly spaced spiral cords (Fig. 4), varying from 11-12 in the first whorl of teleoconch, 14-17 in the second whorl, 18-23 in the third whorl, and 72-76 in the last adult whorl. Each cord bearing microscopic striations. Spiral cords sinuous. Interspaces narrower than cords, evidencing growth lines, particularly anteriorly (Fig. 4). Shell surface glossy, straw yellowish. Operculum elongate, paucispiral, with basal nucleus, widely curved at external margin, angulated at inner margin, yellowish (Fig. 9).
Anatomy

Animal able to completely retract into the shell.

Head-Foot: Eyes absent. Foot relatively small, ovate; anterior end with projecting triangular lateral horns; posterior end widely rounded (Fig. 13). Parapodia absent. Anterior part of cephalic shield rounded; narrow, deep medial sinus, present. Posterior part projecting in two widely separated lobes reaching base of mantle cavity (Figs. 14, 15).

Mantle Cavity: Opening anteriorly, slightly displaced to right (Figs. 13, 15). Mantle border bent dorsally, left side with small papillae on ventral surface (repugnatorial glands?) (Fig. 16). Temporary "siphon" formed by small, triangular, smooth expansion of right mantle border. Plicatidium-like gill comprising few convolute leaflets (Fig. 16), attached at both edges of roof mantle cavity; right anterior part free for about half of its length; left anterior part free for about a sixth of its length. Ciliated ridge ("raphe"), running along roof of mantle cavity, at right of gill (Fig. 16). Second raphe on floor of mantle cavity, present. Both raphes extend posteriorly beyond mantle cavity, running to end of spire, inside pallial caecum. Hypobranchial gland difused on roof of pallial cavity, between dorsal raphe and gill (Fig. 16). Kidney relatively large, running along left side of gill. Heart one half kidney size; auricle anterior to ventricle.

Reproductive System: Gonad with hermaphroditic acini; oocytes developing at blind end of acini. Short hermaphroditic duct connecting with seminal vesicle (also called "ampulla"), serving for autosperm storage prior to ejaculation and for passage of ova toward female glandular complex, present (Fig. 19). Seminal vesicle large, elongate, sigmoid sac, lined by simple epithelium of cubic or low columnar cells (about $12 \mu \mathrm{m}$ height) (Figs. 19, 20). Interior wall of vesicle facing columella ciliated.

Female System: Glandular complex large, elongate, composed of two externally discernible glandular areas (Figs. 19, 29, 30). Single (allosperm) duct opening distally and running parallel to left side of female gland complex (Fig. 19). Allosperm duct with uniform diameter throughout its length; first three-quarters sinuous, becoming straight before opening into small globular sac ("gametolytic gland") (Fig. 21). Histologically, bulb wall composed 

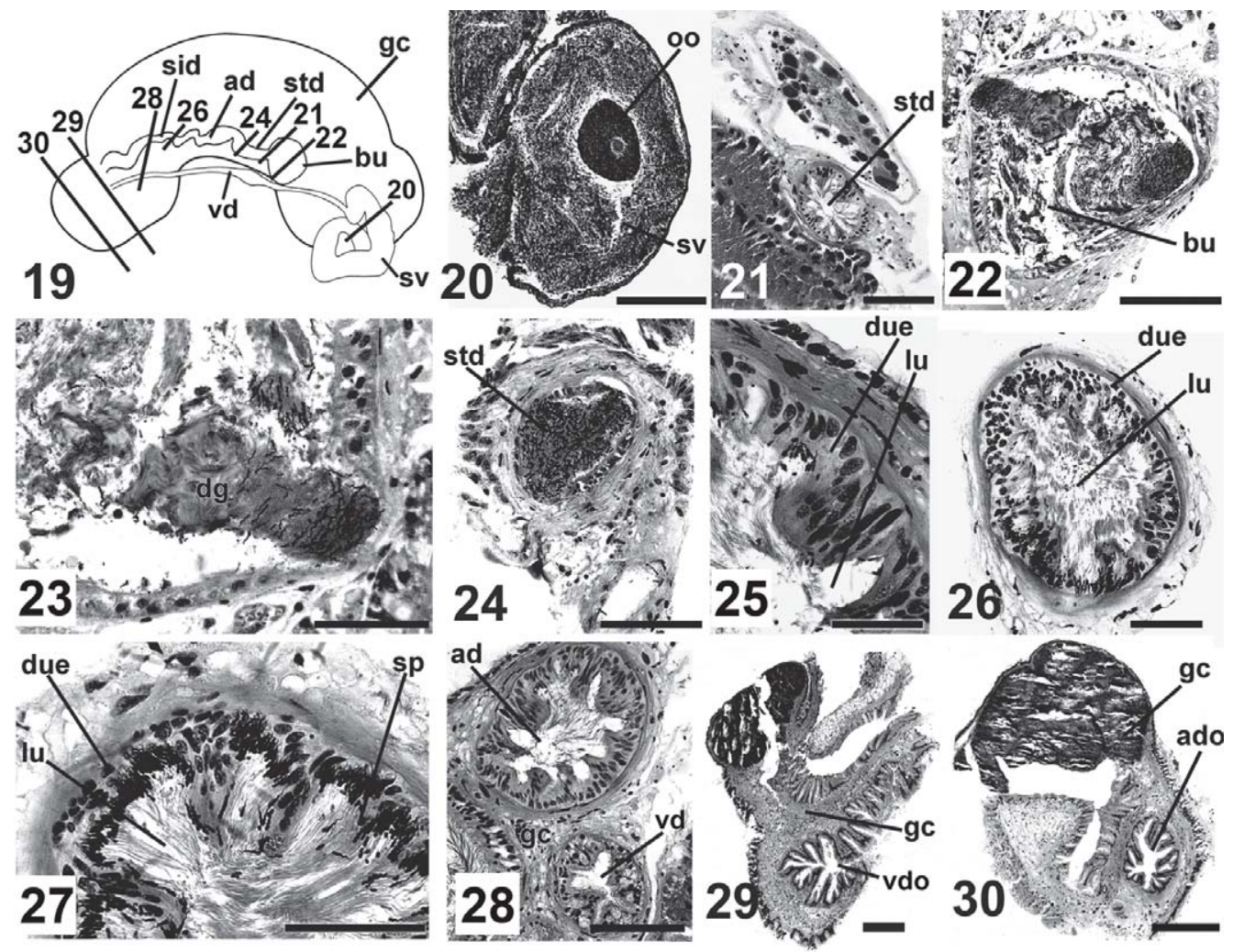

FIGS. 19-30. Neactaeonina argentina, new species: proximal portion of male and female reproductive systems. FIG. 19: Diagram (numbers indicate the histological sections showed in FIGS. 20-30); FIG. 20: Seminal vesicle; FIG. 21: Allosperm duct just before opening into the bulb; FIG. 22: Bulb; FIG. 23: Detail of degenerating gametes within bulb; FIG. 24: Straight portion allosperm duct; FIG. 25: Detail of FIG. 24 showing the duct epithelium; FIG. 26: Sinuous portion of allosperm duct; FIG. 27: Detail of FIG. 26 showing sperm attached to the duct epithelium; FIG. 28: Allosperm duct and vas deferens immersed in the terminal portion of the glandular complex; FIG. 29: Opening of the vas deferens; FIG. 30: Distal opening of allosperm duct. Scale bars: FIGS. 20, $29=200 \mu \mathrm{m}$; FIGS. 21, 22, $28=100 \mu \mathrm{m}$; FIGS. 23-27 = $50 \mu \mathrm{m}$; FIG. $30=30 \mu \mathrm{m}$. ad: allosperm duct; ado: allosperm duct opening; bu: bulb; dg: degenerating gametes; due: duct epithelium; gc: glandular complex; lu: lumen; oo: oocyte traversing the seminal vesicle; sid: sinuous portion of the duct; sp: sperm; std: straight portion of the duct; sv: seminal vesicle; vd: vas deferent; due: duct epithelium; vdo: vas deferent opening.

of low columnar cells (about $15 \mu \mathrm{m}$ height), with vacuolated cytoplasm suggesting some involvement in reabsorption (Figs. 22, 23). Distinct muscular layer absent; lumen usually containing unordered sperm and debris of degenerating gametes which appears as eosinophilic spherules (Figs. 22, 23). Epithelium of allosperm duct formed by single layer of cubic cells, supported by thin connective tissue, ensheathed by somewhat thick layer of circular muscle (Figs. 25-28). Straight portion of duct containing unoriented sperm, whereas in sinuous portion, sperm oriented with heads perpendicular to wall of duct (Figs. 24-27). At distal end, duct of allosperm bulb joining lumen of female duct, to open shortly thereafter close to female genital opening (Fig. 30).

Male System: Vas deferens, arising from seminal vesicle, running anteriorly, parallel to female gland and ventral to allosperm duct (Fig. 19). Epithelium of vas deferens formed by high columnar cells forming several ridges into lumen; duct ensheathed by somewhat thick muscular layer. Vas deferens entering distally into glandular female complex; just before entering duct 


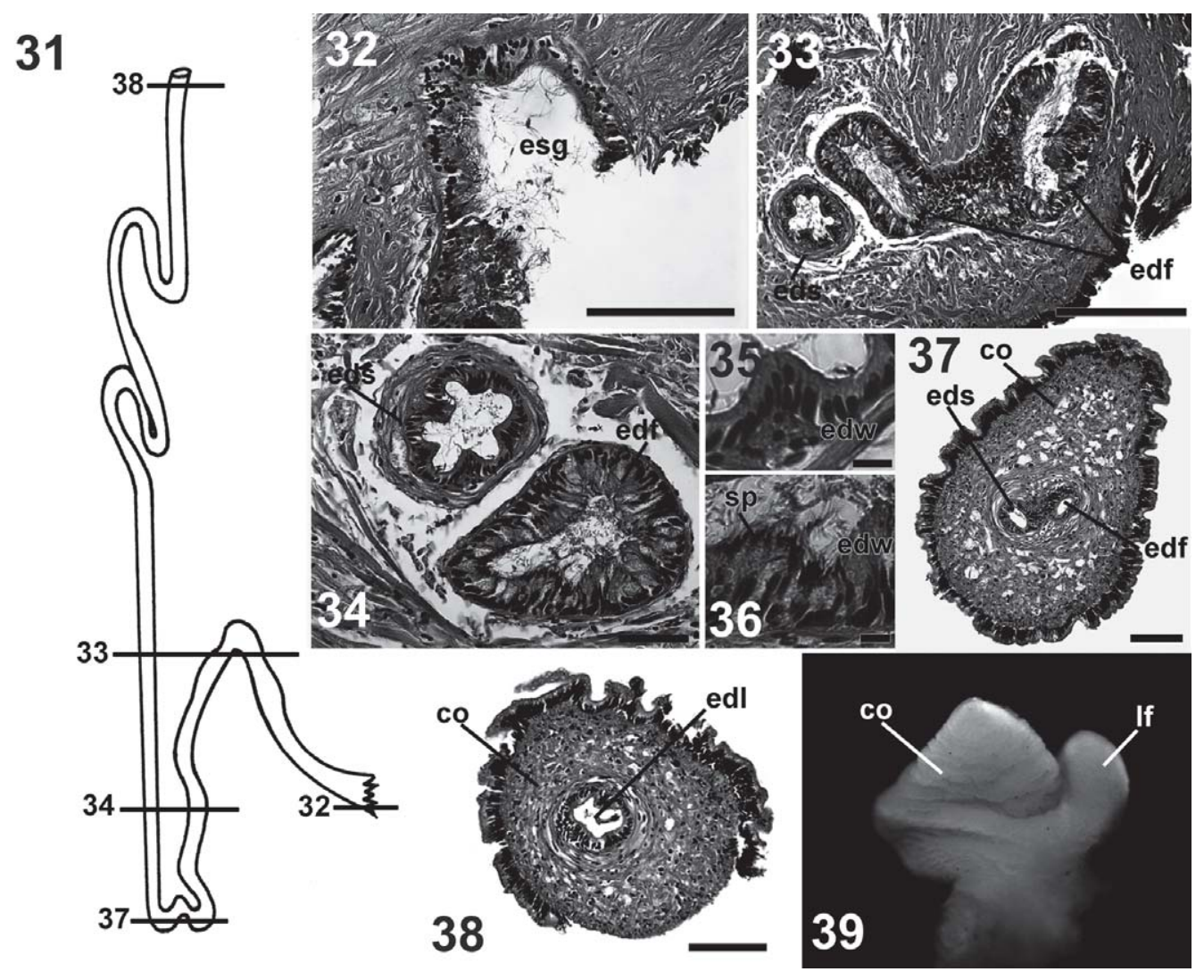

FIGS. 31-39. Neactaeonina argentina, new species: distal portion of male reproductive system. FIG. 31: Schematic drawing (not in scale) of the ejaculatory duct (lines and numbers indicate the histological sections showed in FIGS. 32-34, 37, 38); FIG. 32: External seminal groove; FIGS. 33, 34: Transverse sections of first and second half of ejaculatory duct; FIG. 35: Detail of the second half; FIGS. 36: Detail of the first half showing sperm attached to the duct wall; FIG. 37: Junction of first and second half of ejaculatory duct; FIG. 38: Distal part of ejaculatory duct, close to the tip of the copulatory organ; FIG. 39: Copulatory organ. Scale bars: FIGS. 32, 37, $38=100 \mu \mathrm{m}$; FIG. $33=200 \mu \mathrm{m}$; FIG. $34=50 \mu \mathrm{m}$; FIGS. $35,36=10 \mu \mathrm{m}$. co: copulatory organ; edf: first part of ejaculatory duct; edl: ejaculatory duct lumen; eds: second part of ejaculatory duct; edw: ejaculatory duct wall; esg: external seminal groove; If: lateral flap; sp: sperm.

epithelium lined by large cells with vesiculous cytoplasm (Fig. 28). Shortly after junction of vas deferens and lumen of female glandular complex, vas deferens opening into exterior slightly anterior to female genital opening (Fig. 29). From this point to the base of copulatory organ, male way open, forming ciliated groove (Fig. 32). At base of copulatory organ, closed U-shaped ejaculatory duct opening, after several convolutions, at tip of the copulatory organ (Fig. 31). Just after entering base of copulatory organ, ejaculatory duct enlarges for short length, to continue with U-shaped branch. First half of $U$-shaped duct lined by high columnar glandular epithelium (Figs. 33, 34, 36), with sperm embedded in epithelium (Fig. 36). Duct of second half of $U$ and distal convoluted portion lined by columnar, non-glandular epithelium of variable height, forming five or six ridges toward lumen (Figs. 33, 34, 36, 37). Ejaculatory duct ciliated along its entire length, surrounded by muscular sheath (Fig. 38). Prostatic tissue associated with ejaculatory duct not observed. Copulatory organ triangular, non-retractile, unarmed (Fig. 39). A ventral fold (like a prepuce) at base of copulatory organ expanding into lateral, foliated, anteriorly directed flap (Fig. 39). 
Digestive System: Oral tube short. Buccal mass bulbous, strongly muscular, with three pairs of lateral protractor muscles (laterodorsal, lateral, and lateroventral) (Fig. 17). Pair of large salivary glands, ventrolaterally embracing esophagus (Fig. 17). Salivary glands open at posterodorsal end of buccal mass, above radular ribon. Left salivary duct relatively long; right salivary duct short. Salivary glands flat, highly branched. Posterior portion of esophagus enlarged, forming crop. Stomach saculate, surrounded by female glandular complex. Digestive gland externally visible only at last whorl of visceral mass (Figs. 13-15). Intestine opening at anterior part of stomach, close to esophagus opening. Intestine relatively short, crossing floor of mantle cavity, and running at right side of female glandular complex to open at base of temporal "siphon".
Radula: Composed of approximately 30 rows of 27 teeth each. Rachidian tooth absent. Lateral teeth long, prominently hooked, sharply pointed, smooth, similar in size and shape, except for two outermost rows, where teeth are smaller and less solid, each bearing one or two tubercles close their bases (Figs. 40-42); base of teeth flat, discoidal, solid. Oral cuticle with numerous rows of somewhat irregular, sharply pointed rod-like processes (Fig. 43).

Nervous System: Streptoneurous. Nerve ring prepharyngeal, composed of four large ganglia: one dorsal pair, originating from fusion of cerebral and pleural ganglia, and ventral pair, the pedal ganglia. Right and left cerebropleural ganglia connected by long, thick commissure; pedal ganglia connected by very short commissure; connectives between cerebropleural
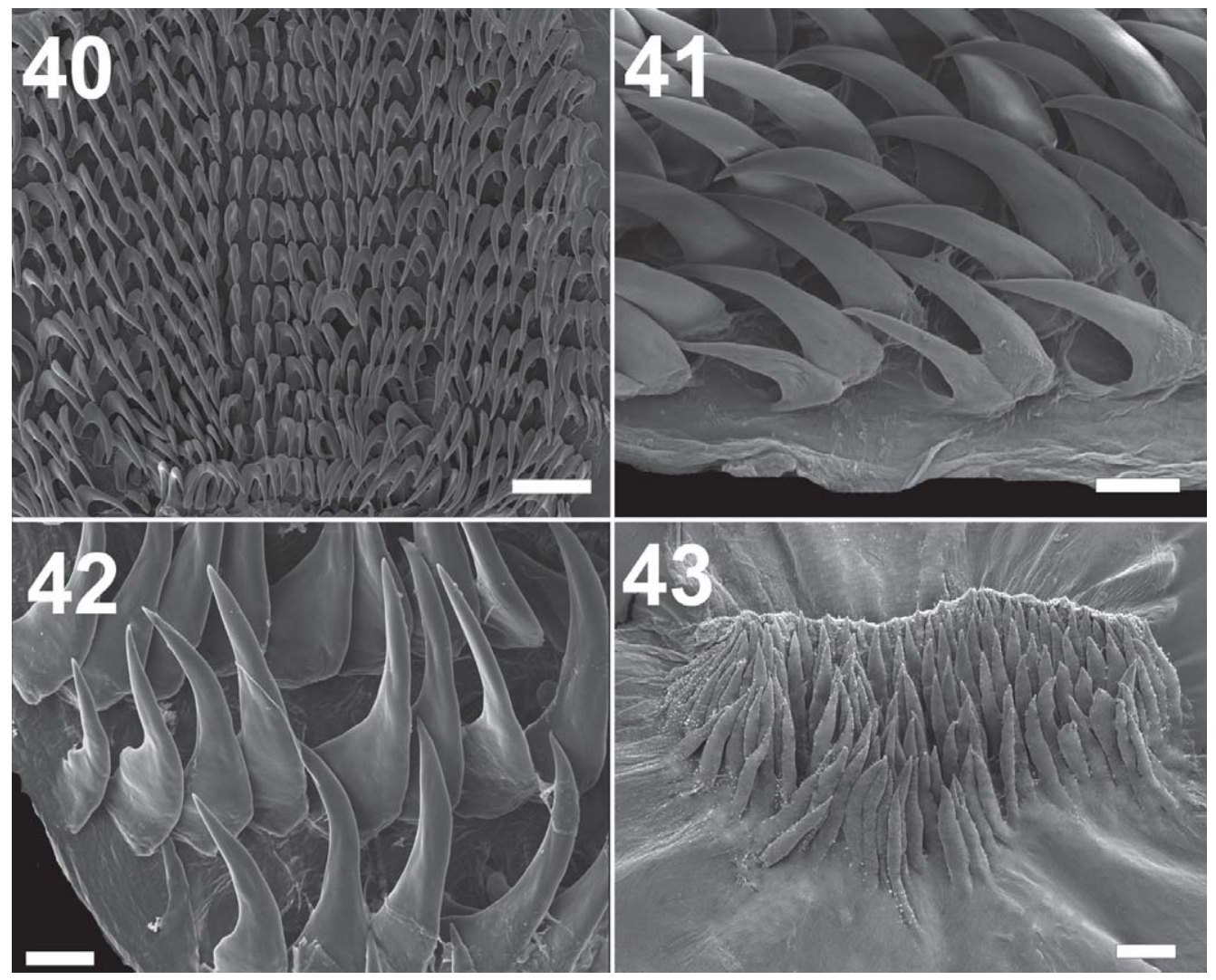

FIGS. 40-43. Neactaeonina argentina, new species. FIGS. 40-42: Radula. FIG. 40: General morphology; FIGS. 41, 42: Detail of lateral teeth. FIG. 43: Oral cuticle. Scale bars: FIG. $40=100 \mu \mathrm{m}$; FIGS. $41-43=20 \mu \mathrm{m}$. 
and pedal ganglia double, short (Fig. 18). Pallial ganglia small, located at sides of buccal mass, clearly separated from cerebropleural and esophageal ganglia by long connectives. Right esophageal ganglion smaller than left, which is represented by only slight enlargement of connective; left connective running below esophagus, joining well-developed subesophageal ganglion (Fig. 18); right connective running over esophagus, where it joins supraesophageal ganglion. From subesophageal and supraesophageal ganglia, two connectives run posteriorly, passing below alimentary canal, to join visceral ganglion.
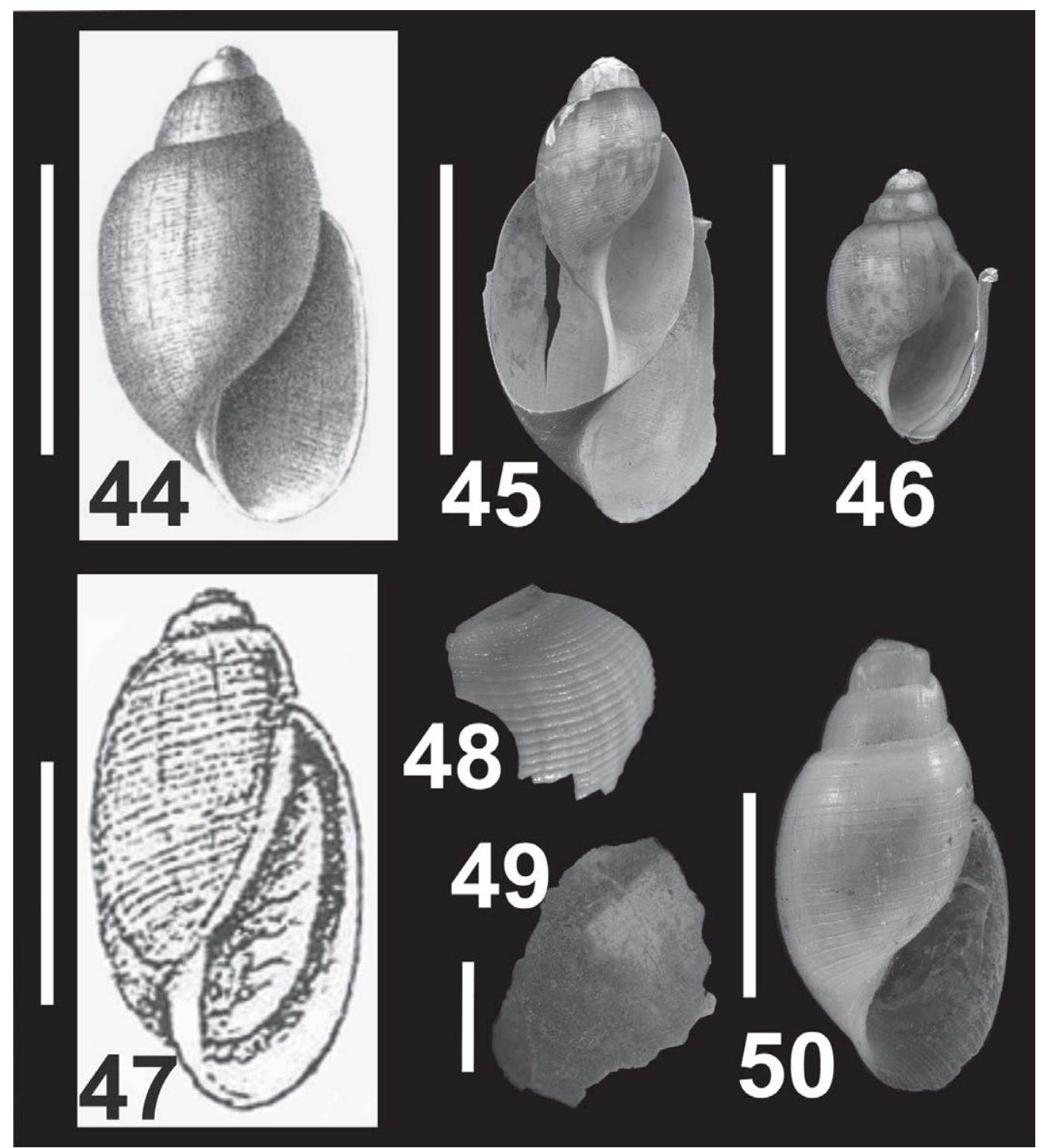

FIGS. 44-50. Other Neactaeonina species. FIGS. 44-46: N. edentula. FIG. 44: Original illustration (Watson, 1886: pl. 47, fig. 6b); FIG. 45: Holotype (BMNH 1887.2.9.2132); FIG. 46: Specimen from King George Island, South Shetland (BMNH 1961619). FIGS. 47, 48: N. cingulata. FIG. 47: Original illustration (Strebel, 1908: pl. 2, fig. 17); FIG. 48: Fragment of the holotype (SMNH 1027); FIG. 49: Fragment of the holotype of $N$. fragilis (ZMB 62978); FIG. 50. Holotype of $N$. inexpectata (NMNZ M.009793). Scale bars: FIGS. 44-46 = $30 \mathrm{~mm}$; FIG. $47=5 \mathrm{~mm}$; FIGS. 49, $50=2 \mathrm{~mm}$. 
Known Distribution

$38^{\circ} 09.88^{\prime}-43^{\circ} 14.18^{\prime} \mathrm{S}, 55^{\circ} 35.42^{\prime}-59^{\circ} 37.27^{\prime} \mathrm{W}$, off Buenos Aires Province; 84-126 m (Fig. 1).

Habitat

Neactaeonina argentina, n. sp., was found in soft-bottoms, being part of the benthic assemblage of the Patagonian scallop Zygochlamys patagonica.

\section{DISCUSSION}

Comparison of Neactaeonina argentina, n. sp., with other Neactaeonina Species

Neactaeonina argentina, n. sp., is most similar to N. edentula (Figs. 44-46), from which it differs in having a more acute spire with shouldered whorls and deeply channeled suture. According to Watson (1886) sutures in N. edentula are "axially impressed rather than channeled".

Neactaeonina argentina, n. sp., differs from $N$. cingulata (Figs. 47, 48) in having a lower spire, and a different number of lateral teeth. Thiele (1912) described the radula of $N$. cingulata as having one central tooth and 7 to 8 laterals at each side - interpreted as 8.0 .8 by Hoffmann (1932-1940) - whereas $\boldsymbol{N}$. argentina, n. sp., has 27 laterals in each row. The morphology of the lateral teeth, however, shows no differences in $\mathbf{N}$. argentina, $\mathrm{n}$. sp., and $N$. cingulata.

Compared with Neactaeonina inexpectata (Fig. 50), $\boldsymbol{N}$. argentina, n. sp. has a more solid shell, sculptured with a greater number of spiral cords and a wider columellar callus. Furthermore, in $N$. inexpectata the spire whorls are rounded, whereas in $\boldsymbol{N}$. argentina, n. sp., whorls are nearly straight.

The affinities between Neactaeonina argentina, n. sp., and N. fragilis are difficult to establish. The original description of $N$. fragilis is poor, lacking in detail and illustration. The type material consists of fragments of a single shell (Fig. 49), which show a shell thinner than in $\mathbf{N}$. argentina, n. sp., with more delicate sculpture. After the original description, the only subsequent references to this species are those by Hedley (1916) and Hain (1990), who tentatively assigned to $N$. fragilis specimens from Adelia Land and Weddell Sea, respectively. Hedley (1916) did not describe or figure the studied specimens, and Hain (1990: plate 8, fig. 9) only figured the general shell outline of a single specimen which differs from $\boldsymbol{N}$. argentina, $\mathrm{n}$. sp., in having a depressed spire. Dell (1990) pointed out that "[Neactaeonina] fragilis may ultimately prove to be indistinguishable from [N.] edentula".

The overall similarities in shell morphology, radula, and oral cuticle of Neactaeonina argentina, n. sp., and N. cingulata, the type species of the genus, clearly support the generic status of the new species. Information on the soft part anatomy of the other Neactaeonina species is unknown.

\section{Suprageneric Placement of Neactaeonina}

Although the text by Thiele (1912) containing the description of Neactaeonina is printed immediately following the text corresponding to Acteon antarcticus, the familial placement of this genus was not formally proposed until 14 years later, when Odhner (1926) placed it into the Acteonidae. This was followed by all subsequent authors (Thiele, 1931 [as Actaeonidae]; Powell, 1951, 1960; Carcelles, 1953; Dell, 1990; Hain, 1990 [as Acetonidae, by misspelling]); however, the generic placement of Neactaeonina was never properly justified. In fact, Odhner (1926) only pointed out some differences between Neactaeonina and Acteon Montfort, 1810 (the type genus of Acteonidae), not discussing on the similarities that allowed him to unite the two genera in the same family.

The Acteonoidea were traditionally regarded as comprising three families: Acteonidae, Aplustridae, and Bullinidae (Rudman, 1972a; Burn \& Thompson, 1998; Bouchet \& Rocroi, 2005). Göbbeler \& Klussmann-Kolb (2010), performed the first phylogenetic analysis of these families, concluding that only two of these clades appear well-supported: Acteonidae (without Rictaxis) and Aplustridae (including Bullina and Rictaxis). The characters previously described for Neactaeonina may be therefore now traced in Göbbeler \& Klussmann-Kolb's (2010) phylogeny.

\section{Is Neactaeonina Actually an Acteonid?}

Neactaeonina has an elongate, strongly calcified shell, with well-developed operculum; a small and unlobed foot; a short oral tube; absence of central radular tooth; mantle cavity opening anteriorly; and nervous system with long conective between the supraesophageal ganglion and the right cerebro-pedal ganglia. It is thus evident that Neactaeonina exhibits the characters reported as diagnostic for the Acteonidae. 
Comparison of Neactaeonina with otherActeonids

The radula of Neactaeonina clearly differs from that of Acteon both in the number and morphology of teeth. Acteon species have numerous, minute, denticulate, and identical teeth - radular formula: 100+.0.100+ (Mikkelsen, 1996); 50-150.0.50-150 (Gosliner, 1996). In contrast, Neactaeonina species have a minor number of teeth, with the two outermost rows smaller; the teeth in Neactaeonina species are larger and almost smooth (except for one or two tubercles close to the bases of the outermost laterals). The radulae of Neactaeonina species closely resemble that of Crenilabrum exilis (Jeffreys, 1870), Japonacteon pusillus (Forbes, 1843), and Maxacteon cratericulatus (Hedley, 1906), respectively described by Bouchet (1975: fig. 1A), Bouchet (1975: fig. 3), and Rudman (1972a: fig 8A): all of them have sharply pointed laterals. However, in Neactaeonina, such as in Japonacteon and Maxacteon, the rachidian tooth is absent, whereas in $C$. exilis (according to Bouchet, 1975), this tooth is present, although reduced at the base. Japonacteon has differentiated marginal and lateral teeth, and Maxacteon has bicuspid laterals.

The oral cuticle in Neactaeonina is composed of rod-like processes resembling lateral teeth, whereas in Acteon species these processes are multicusped (Marcus, 1972; Gosliner, 1994, 1996: fig. 2.3B). The oral cuticle of Neactaeonina is similar to that described by Bouchet (1975: fig. 1C) for Crenilabrum exilis, but unlike those of Pupa species (described by Rudman, 1972a), which are similar to those of Acteon species.

The opening of the single allosperm sac (composed of a seminal receptacle in tandem with the gametolytic gland) in Neactaeonina argentina, n. sp., is distally with respect to the gonad (i.e., near the genital opening), whereas in Acteon species the opening is proximal (i.e., near the gonad), at the level of the seminal vesicle (Johannson, 1954; Fretter \& Graham, 1954; Ghiselin, 1966; Gosliner, 1981). According to Gosliner (1994), the presence of only one sperm storage "organ" is a derived condition for the acteonids; the primitive condition for the Actaeonoidea is the presence of two allosperm sacs: the proximal, functioning as seminal receptacle, and the distal serving as gametolytic gland, as for example in Pupa and Maxacteon species (Rudman, 1972b; Gosliner, 1981).

The male system in Neactaeonina argentina, n. sp., is peculiar, resulting from the combination of a closed spermatic duct running along- side the female glandular complex (the vas deferens) and an external groove, carrying the sperm from the end of the vas deferens to the base of the copulatory organ; from this point, another closed portion (the ejaculatory duct) carry sperm to the tip of the copulatory organ. Interestingly, the first (glandular) portion of the ejaculatory duct seems to be involved in the temporary sperm storage before ejaculation. In Acteon species, the male genital duct is closed, and the vas deferens is continuous with the ejaculatory duct (Fretter \& Graham, 1954; Johansson, 1954). The latter condition was also reported for Pupa and Maxacteon species (Rudman, 1972b), and was previously regarded as characteristic of the Acteonoidea (Gosliner, 1994).

Associated with the vas deferens, a glandular portion forming a prostate (the so-called "pallial prostate") was described for some acteonids (Johannson, 1954; Fretter \& Graham, 1954; Gosliner, 1994; Mikkelsen, 1996). In Neactaeonina argentina, n. sp., no prostatic tissue associated with any portion of the vas deferens, was observed.

The copulatory organ in Acteon species is a straight, tubular structure (Marcus, 1972, 1974), whereas in Neactaeonina argentina, n. sp., the copulatory organ is a triangular and somewhat flattened structure. Fretter \& Graham (1954) reported in Acteon tornatilis the presence of a shallow basal fold, like a prepuce; a similar structure is also present in $N$. argentina, n. sp. (this study).

In Neactaeonina species the salivary glands are profusely branched, forming flat or laminar structures embracing part of the esophagus. In Acteon species, as in Pupa, Maxacteon, and Crenilabrum species, the salivary glands are tubular, elongate, and running parallel to the esophagus (Rudman, 1972a, b; Bouchet, 1975; Gosliner, 1994).

Neactaeonina argentina, n. sp., lacks eyes, whereas Acteon has well-developed eyes.

In shell morphology, species of Neactaeonina clearly differ from those of Acteon in having a smooth columella (without columellar folds) and the shell surface sculptured with spiral cords (punctated spiral grooves are present in Acteon species).

Significance of the New Species in the Context of Present Knowledge of the Geographic Distribution of the Genus

The new species here described represents the northernmost record for Neactaeonina, a 
genus thus far known only from Antarctica, New Zealand, and the Scotia Arc islands. However, the present finding does not necessarily imply the extension of the distribution of the genus to a different biogeographic realm: in fact, the localities where the new species was collected correspond to an area affected by the so-called sub-Antarctic waters, influenced by the Malvinas oceanic current, which is a branch of the West Wind Drift extending northwards, along the outer margin of the Argentine shelf, up to $23^{\circ} \mathrm{S}$ (off Brazil) (Boltovskoy et al., 1999). In fact, the benthic assemblages occurring at the sites where Neactaeonina argentina, $\mathrm{n}$. sp., was collected include several well known sub-Antarctic taxa: the bivalves Zygochlamys patagonica (King, 1832), Limatula pygmaea (Philippi, 1845), Hiatella meridionalis d'Orbigny, 1846; the gastropods Calyptraea pileolus d'Orbigny, 1841, Fusitriton magellanicus (Röding, 1798), Odontocymbiola magellanica (Gmelin, 1791), Adelomelon ancilla ([Lightfoot], 1786); the sponges Tedania massa Ridley \& Dendy, 1886, Tedania mucosa Thiele, 1905, Hymedesmia antarctica Hentschel, 1914, Iophon proximum (Ridley, 1881), Phorbas leptochela (Hentschel, 1914), Tedania charcoti Thiele, 1905, Isodictya verrucosa (Topsent, 1913), Haliclona kerguelensis (Hentschel, 1914); the echinoderms genera Labidiaster Lütken, 1871, Odontaster Verrill, 1880, Acodontaster Verrill, 1899, Porania Gray, 1840, Ophiacanta Müller \& Troschel, 1842, Gorgonocephalus Leach, 1815, Sterechinus Koehler, 1901; and the cnidarian genera Alcyonium Linnaeus, 1758, Thouarella Gray, 1870, and Actinostola Verrill, 1883 (Bertolino et al., 2007; Roux et al., 2005; Schejter et al., 2006; Schejter unpubl. data). The above information confirms that Neactaeonina is a genus clearly associated with the sub-Antarctic and Antarctic waters.

Species Erroneously Reported under Neactaeonina

Marcus (1974) reported under Neactaeonina, Acteon (Actaeonina) chariis Watson, 1881, a living species from the Azores. The only argument for this generic placement was that "The genus Acteonina d'Orbigny, 1850, was erected for a fossil species". Thiele (1912: 220) and Zilch (1959-60: 14) retained the use of Acteonina for fossil shells. The radula and soft part anatomy of Acteon (Actaeonina) chariis are unknown; however, several shell characters, such as the presence of a rela- tively high spire, the sinuous ("hair-like") growth lines, and the protoconch "extremely blunt", strikingly different from the condition present in the sub-Antarctic and Antactic species of Neactaeonina. Mikkelsen (1995), Malaquias (2001), and Cervera et al. (2004) retained this species under Actaeonina.

\section{ACKNOWLEDGEMENTS}

We would like to express our gratitude to K. Sindemark, A. MacLellan, B. Marshall, and $M$. Glaubrecht, for sending the types or photographs of the types of the Neactaeonina species housed at their Museums; the crew of the RV "Capitán Cánepa", technicians and biologists, participating during the cruises for helping during sample collection; the INIDEP librarians for helping with bibliography; and D. Waloszek and O. Heilmayer for helping us with the translations of some German original descriptions. P. Mikkelsen and an anonymous reviewer provided valuable criticisms that improved the manuscript.

The authors are members of the Consejo Nacional de Investigaciones Científicas y Técnicas (CONICET), Argentina. This study was partially founded by PICT 38015 . This is INIDEP Contribution N N 1623.

\section{LITERATURE CITED}

BERTOLINO, M., L. SCHEJTER, B. CALCINAI, C. CERRANO \& C. BREMEC, 2007, Sponges from a submarine canyon. Pp. 189-201, in: M. R. Custódio, E. Hajdú, G. Lobo Hajdú \& G. MuRICY, eds., Porifera research: biodiversity, innovation and sustainability. Museo Nacional, Río de Janeiro, 684 pp.

BOLTOVSKOY, D., M. GIBBONS, L. HUTCHINGS \& D. BINET, 1999, General biological features of the South Atlantic. Pp. 1-42, in: D. BoltovskoY, ed., South Atlantic zooplankton, Vol. 1, The Netherlands, xii $+868 \mathrm{pp}$.

BOUCHET, P., 1975, Opistobranches de profondeur de l'Oceán Atlantique: I. Cephalaspidea. Cahiers de Biologie Marine, 16: 317-365.

BOUCHET, P. \& J. P. ROCROI, 2005, Classification and nomenclator of gastropod families. Malacologia, 47: 1-397.

BURN, R. \& T. E. THOMPSON, 1998, Order Cephalaspidea. Pp. 943-959, in: P. L. BeEsLEY, G. J. B. Ross \& A. Wells, eds., Mollusca. The southern synthesis. CSIRO Publishing, Melbourne, 1,234 pp.

CARCELLES, A., 1953, Catálogo de la malacofauna Antártica Argentina. Anales del Museo Nahuel Huapí, 3: 155-250, pls. 1-5. 
CERVERA L G CALADO C GAVAIA M. A E. MALAQUIAS, J. TEMPLADO, M. BALLESTEROS, J. C. GARCÍA GÓMEZ \& C. MEGINA, 2004, An annotated and updated checklist of the opisthobranchs (Mollusca: Gastropoda) from Spain and Portugal (including islands and archipelagos). Boletín del Instituto Español de Oceanografía, 20(1-4): 5-111.

DELL, R. K., 1956, The archibenthal Mollusca of New Zealand. Bulletin of the Dominion Museum, 18: 1-253.

DELL, R. K., 1990, Antarctic Mollusca with special reference to the fauna of the Ross Sea. Bulletin of the Royal Society New Zealand, 27: 1-311.

FRETTER, V. \& A. GRAHAM, 1954, Observations on the opistobranch mollusc Acteon tornatilis (L.). Journal of the Marine Biological Association of the United Kingdom, 33(3): 565-585.

GHISELIN, M. T., 1966, Reproductive function and the phylogeny of opistobranch gastropods. Malacologia, 3(3): 327-378.

GÖBBELER K. \& A. KLUSSMANN-KOLB, 2010, The phylogeny of the Acteonoidea (Gastropoda): molecular systematics and first detailed morphological study of Rictaxis punctocaelatus (Carpenter, 1864). Journal of Molluscan Studies, 76(4): 303-316.

GOSLINER, T. M., 1981, Origins and relationships of primitive members of the Opistobranchia (Mollusca: Gastropoda). Biological Journal of the Linnean Society, 16: 197-225.

GOSLINER, T. M., 1994, Gastropoda: Opisthobranchia. Pp. 253-335, in: F. W. HARRISON \& A. J. KoHn, eds., Microscopic anatomy of invertebrates, 5, Mollusca I. Wiley-Liss, New York, $390 \mathrm{pp}$.

GOSLINER, T. M., 1996, The Opistobranchia. Pp. 161-228, in: P. H. Scott, J. A. Blake \& A. L. LISSNER, eds., Taxonomic atlas of the benthic fauna of the Santa Maria Basin and western Santa Barbara Channel, vol. 9, The Mollusca. Part 2. The Gastropoda. Santa Barbara, California, Santa Barbara Museum of Natural History, viii +228 pp

HAIN, S., 1990, The benthic seashells (Gastropoda and Bivalvia) of the Weddell Sea, Antarctica. Berichte zur Polarforschung, 70: 1-211, pls. 1-30.

HEDLEY, C., 1916, Mollusca. Australasian Antarctic Expedition 1911-1914. Scientific Reports, C, Zoology and Botany, 4(1): 1-80, pls. 1-9.

HOFFMANN, H., 1932-1940, Opistobranchia. Bronn's Klassen und Ordnungen des Tierreichs. 3: Mollusca: Abt. II, Gastropoda, 3(1): xi + 1,247 pp., 1 pl.; (2): 90 pp.

JOHANNSON, J., 1954, On the pallial gonoduct of Acteon tornatilis (L.) and its significance for the phylogeny of the Euthyneura. Zoologiska Bidrag fran Upssala, 30: 223-231.

MALAQUIAS, M. A. E., 2001, Updated and annotated checklist of the opisthobranch molluscs (excluding Thecosomata and Gymnosomata), from the Azores archipelago (North Atlantic Ocean, Portugal). Iberus, 19(1): 37-48.
MARCUS, E., 1972, On some Acteonidae (Gastropoda, Opistobranchia). Papéis Avulsos de Zoología, 25(19): 167-188.

MARCUS, E. d. B.-R., 1974, On some Cephalaspidea (Gastropoda: Opisthobranchia) from the western and middle Atlantic warm waters. Bulletin of Marine Science, 24(2): 300-317.

MIKKELSEN, P. M., 1995, Cephalaspid opisthobranchs of the Azores. Açoreana, Supplement: 193-215

MIKKELSEN, P. M., 1996, The evolutionary relationships of Cephalaspidea s.I. (Gastropoda: Opistobranchia): a phylogenetic analysis. Malacologia, 37(2): 375-442.

ODHNER, N. H., 1926. Die Opistobranchien. Further zoological results of the Swedish Antarctic Expedition 1901-1903, 2(1): 1-100, pls. 1-3.

POWELL, A. W. B., 1951, Antarctic and Subantarctic Mollusca: Pelecypoda and Gastropoda collected by the ships of the Discovery Committee during the years 1926-1937. Discovery Reports, 26: 49-196, pls. 5-10.

POWELL, A. W. B., 1960, Antarctic and Subantarctic Mollusca. Records of the Auckland Institute and Museum, 5: 117-193.

ROUX, A., C. BREMEC, L. SCHEJTER \& D. GIBERTO, 2005, Benthic invertebrates by-catch of demersal fisheries: a comparison between Subantactic and Antarctic shelf waters $\left(45^{\circ} \mathrm{S}-57^{\circ} \mathrm{S}\right)$. Berichte zur Polar und Meeresforschung, 507 179-181.

RUDMAN, W. B., 1972a, Structure and functioning of the gut in the Bullomorpha (Opisthobranchia). Part II. Acteonidae. Journal of Natural History, 6(3): 311-324

RUDMAN, W. B., 1972b, A study of the anatomy of Pupa and Maxacteon (Acteonidae, Opisthobranchia), with an account of the breeding cycle of Pupa kirki. Journal of Natural History, 6(6): 603-619.

SCHEJTER, L., B. CALCINAI, C. CERRANO, M. BERTOLINO, M. PANSINI, D. GIBERTO \& C. BREMEC, 2006, Porifera from the Argentine Sea: diversity in Patagonian scallop beds. Italian Journal of Zoology, 73(4): 373-385.

THIELE, J., 1912, Die Antarktischen Schnecken und Muscheln. Deutsche Südpolar Expedition 1901-1903, 13[Zoologie 5](2): 183-285, pls. 11-19.

THIELE, J., 1931, Handbuch der systematischen Weichtierkunde Vol. 2. G. Fisher, Jena, pp. 377-778.

WATSON, R. B., 1886, Report of the Scaphopoda and Gasteropoda collected by H.M.S. Challenger during the years 1873-76. In: Reports of the Exploring Voyage of the H.M.S. Challenger during the years 1873-76, Zoology, 15(41): 1-608; (42): 609-756, pls. 1-50

ZILCH, A., 1959-1960, Gastropoda (Euthyneura). Schindewolf, Otto H. Handbuch der Paläozoologie, 6(2): xiii + 834 pp.

Revised ms. accepted 5 October 2010 